\title{
ZASTOSOWANIE WYBRANYCH TECHNIK LEAN MANAGEMENT \\ W PROJEKTACH INFORMATYCZNYCH
}

https://doi.org/10.33141/po.2019.01.07

\section{Bartłomiej Gładysz}

\section{Wprowadzenie}

W ielu autorów podejmowało tematykę definiowania technologii informacyjnych i komunikacyjnych (ang. ICT - Information and Communication Technologies) (Zuppo, 2012). ICT jest rozszerzonym pojęciem na określenie technologii informacyjnych (ang. IT - Information Technologies), które ma na celu podkreślenie roli komunikacji, a w szczególności telekomunikacji. ICT to technologie wykorzystywane przez ludzi i organizacje $\mathrm{w}$ celu przetwarzania informacji oraz komunikowania się (Zhang i in., 2008). Pomimo iż literalnie pojęcie IT jest węższe niż ICT, w praktyce są one na ogół używane zamiennie, co przyjęto $\mathrm{w}$ niniejszym opracowaniu. $\mathrm{W}$ ramach branży IT istnieją dwa nierozłączne, wzajemnie się przenikające obszary, tj. sprzęt (instalacja, wykorzystanie i utrzymanie) oraz oprogramowanie (wytwarzanie, rozwój i utrzymanie). Oba te obszary są obiektem możliwego wykorzystania zasad lean management (Womack, Jones, 1996). Można wyróżnić dwa wymiary współistnienia lean i IT w przedsiębiorstwach (Bell, Orzen, 2016):

- lean w IT, tj. wykorzystywanie zasad i narzędzi lean w celu usprawniania organizacji procesów związanych z wdrażaniem i działaniem IT w przedsiębiorstwie,

- IT w lean, tj. wykorzystywanie IT w celu wyszczuplenia procesów i realizacji zasad lean.

$\mathrm{W}$ niniejszym artykule rozważaniom poddano jedynie lean w IT. Przykładowe zastosowania IT w lean można znaleźć m.in. w innych pracach autora (Gladysz i in., 2018; Gladysz, Buczacki, 2017). Przykłady wykorzystania zasad lean w IT, w szczególności w odniesieniu do procesu wytwarzania oprogramowania, opisali P. Rodriguez i inni (2014). Wdrożenia IT i programy lean mogą ze sobą konkurować na poziomie kadry wysokiego szczebla, gdyż obszary te wymagają innych podstaw i umiejętności. Jednak co do zasady nie wykluczają się. Celem niniejszego artykułu jest przeanalizowanie specyfiki zastosowania zasad i wybranych technik lean w projektach informatycznych, szczególnie w wytwarzaniu oprogramowania i relacji pomiędzy szczupłym wytwarzaniem oprogramowania a innymi metodami, technikami i modelami stosowanymi w branży IT. Aby osiągnąć sformułowany cel, przeprowadzono analizę stanu wiedzy oraz studium przypadku polskiej małej firmy z branży IT. Wynikiem pracy jest zestawienie oraz omówienie znanych z literatury praktyk lean możliwych do stosowania w branży IT oraz przykład zastosowania wybranych $\mathrm{z}$ nich. Zestawienie może

\author{
Przegląd Organizacji, Nr 1 (948), 2019, ss. 53-61 \\ www.przegladorganizacji.pl \\ ๑Towarzystwo Naukowe Organizacji i Kierownictwa
} (TNOiK) służyć praktykom jako wskazówka i model referencyjny w zakresie możliwości usprawniania procesów w branży IT w oparciu o zasady i techniki znane z lean. Jakkolwiek istnieją opisy zastosowań zasad i wybranych technik lean $\mathrm{w}$ projektach informatycznych, to nie jest oczywiste, czy tego rodzaju praktyki mają zastosowanie w specyfice polskich firm z sektora MŚP. Z uwagi na tak sformułowany problem badawczy celowe jest wykorzystanie studium przypadku jako metody badawczej, gdyż celem jest jakościowe przedstawienie zjawiska i uchwycenie jego kontekstu, co może stanowić wartość poznawczą dla organizacji o podobnym charakterze działalności. Studium przypadku jest tutaj właściwe, gdyż granice między przypadkiem a jego kontekstem są niemożliwe do jednoznacznego uchwycenia. Jest też wartościowe dla praktyki gospodarczej, gdyż opis przypadku może stanowić przykład dobrej praktyki dla biznesu funkcjonującego w podobnych warunkach i charakteryzującego się podobnymi cechami organizacyjnymi (Wójcik, 2013). Charakter postawionych pytań badawczych potwierdza słuszność doboru studium przypadku jako metody (rys. 1).

Projekty informatyczne (większe lub mniejsze) są nieodzowne w działalności nie tylko firm świadczących usługi w szeroko rozumianej branży IT, ale niemalże każdej organizacji (chociażby jako klienta). Stąd też efektywne prowadzenie tego typu projektów jest i będzie istotnym problemem w działalności wielu przedsiębiorstw. Lean management zaś dostarcza zestawu potencjalnie możliwych do wykorzystania technik w celu wyszczuplania różnego rodzaju procesów, w tym także tych związanych $\mathrm{z}$ realizacją projektów informatycznych. Rekapitulując, problemem badawczym podjętym $\mathrm{w}$ pracy jest identyfikacja elementów lean management mających zastosowanie $\mathrm{w}$ projektach informatycznych oraz przedstawienie skutecznego zastosowania wybranych technik lean management (VSM i kanban) w polskim małym przedsiębiorstwie realizującym projekty informatyczne.

\section{Lean w IT - stan wiedzy}

$\mathbf{R}$ ozpatrując procesy związane z wykorzystaniem IT, można wyróżnić dwa podstawowe strumienie, tj. działania będące podstawą prowadzenia biznesu oraz działania pomocnicze. Rola IT w przedsiębiorstwach jest kluczowa i wiele procesów należy traktować jako podstawowe lub 


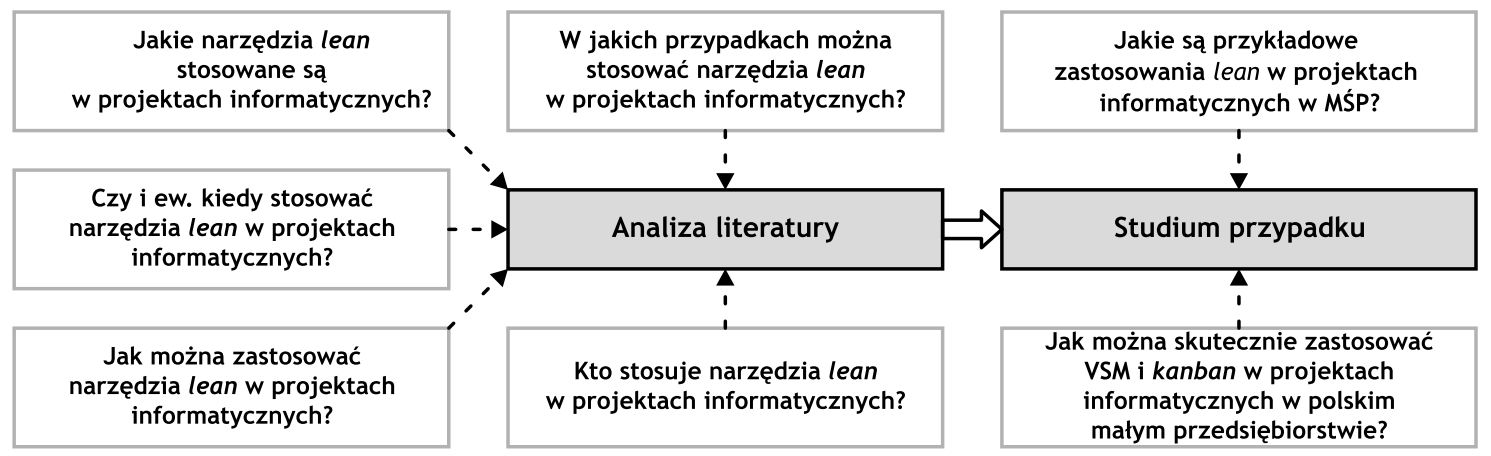

Rys. 1. Pytania i metody badawcze

Źródło: opracowanie własne

wręcz istotne strategicznie dla firmy. Wśród pomocniczych procesów można wyróżnić m.in. utrzymanie sieci komunikacyjnej w biurze, zarządzanie sprzętem, tworzenie kopii zapasowych.

Dla procesów IT można mapować strumień wartości (ang. VSM - Value Stream Mapping) analogicznie jak dla procesów produkcyjnych. Mapa strumienia wartości przyjmuje zazwyczaj znacznie mniej złożoną formę niż dla procesów produkcyjnych. Główną trudnością napotykaną dla VSM w IT jest konieczność mapowania procesów, które często nie kończą się produktem materialnym i które nie są widoczne. VSM rozpoczyna się, analogicznie jak w przypadku produkcji, od wytypowania procesu, który jest potencjalnym źródłem strat. Następnie należy proces podzielić na zadania, które wymiarowane są oczekiwanym czasem ich realizacji. W kolejnym kroku określa się czas oczekiwania (pomiędzy realizacją kolejnych zadań). Istotne jest, aby mapa zaczynała i kończyła się na kliencie lub możliwie blisko rzeczywistego klienta.

Zaadaptowane do wytwarzania oprogramowania zasady lean są następujące (Poppendieck, Poppendieck, 2003; 2007):

- eliminowanie strat,

- wzmacnianie procesu uczenia się,

- podejmowanie decyzji w najpóźniejszym dopuszczalnym momencie,

- dostarczanie zadań w najwcześniejszym możliwym momencie,

- delegowanie uprawnień i autoryzowanie,

- zapewnienie integralności oprogramowania,

- myślenie globalne o całym systemie i rozwiązaniu.
Autorzy wskazują straty w IT (wytwarzaniu oprogramowania), które należy eliminować. Szczupłe wytwarzanie oprogramowania powinno skupić się wg zasady $\mathrm{Pa}$ reto na wytworzeniu niewielu istotnych funkcjonalności, które zaspokoją większość wymagań. Jeżeli wymagania ulegają nieustannym zmianom, to oznacza, że są specyfikowane zbyt wcześnie. Jeśli zaś cykle testów i poprawek powtarzają się wielokrotnie, oznacza to, że testowanie jest realizowane zbyt późno. Bariery organizacyjne mają szczególny wpływ na proces komunikowania się i mogą wydłużać czas realizacji procesu. Znalezienie źródeł strat może być kłopotliwe w IT. Dlatego T. Rivera (2010) proponuje, aby VSM tworzyć, biorąc pod uwagę typowe źródła strat (tab. 1).

W różnych miejscach organizacji IT tworzą się kolejki. Prostym przykładem oczekiwania na możliwość rozpoczęcia zadania jest oczekiwanie pracownika na autoryzację kierownika. Zaległości (lista zadań) mają podobny charakter do oczekiwania. Zarządzanie listą zadań, np. wymagań dla oprogramowania, jest czasochłonne, należy je zatem traktować jako stratę. T. Rivera (2010) proponuje, aby lista wymagań nie była dłuższa niż możliwa do zrealizowania w 2 najbliższych wersjach oprogramowania. Mniej istotne jest dokładne określenie długości listy niż przygotowanie listy możliwej do realizacji w przewidywalnej przyszłości. Eliminowanie strat wynikających z backlogów można zacząć od wykreślania tych wymagań, których nie da się zrealizować w przewidywalnej przyszłości (Poppendieck, Poppendieck, 2007). W dalszej kolejności można pozostawić w backlogu jedynie wymagania istotne i bardzo istotne. Dalej należy oszacować pracochłonność

Tabela 1. Straty w IT

\begin{tabular}{|l|l|}
\hline \multicolumn{1}{|c|}{ Poppendieck i Poppendieck (2003; 2007) } & \multicolumn{1}{|c|}{ Rivera (2010) } \\
\hline Zbędne procesy i funkcjonalności & Oczekiwanie na możliwość rozpoczęcia zadania \\
Zmiany i poprawki & Backlogi- z ang. zaległości \\
Bariery organizacyjne i zadania zarządcze & Niepotrzebne cykliczne spotkania \\
Praca wykonana częściowo & Poprawki wadliwych elementów rozwiązania (ang. callback) \\
Wielozadaniowość & Wielokrotne zatwierdzanie \\
Oczekiwanie i zbędny ruch & Integracja części rozwiązania, które w celu skrócenia terminu \\
& zakończenia są wykonywane równolegle \\
& Długie czasy trwania testów \\
\hline
\end{tabular}


i ocenić, czy realizacja pozostałych wymagań jest możliwa w najbliższej przyszłości. Jeśli nie, to rozważyć zwiększenie zasobów. Kolejki i listy zadań są buforami pomiędzy organizacjami i pracownikami, więc prowadzą do wydłużenia czasu zakończenia projektu. Można tu stosować teorię kolejek, analogicznie jak w przypadku pracy serwerów. Praca powinna być ograniczona tak, aby była możliwa do zrealizowania. Spotkania przeglądowe mogą nie wnosić żadnej wartości. Należy się przyjrzeć czasowi poświęcanemu spotkaniom i zadecydować, czy są one niezbędne. Niewłaściwa obsługa informacji zwrotnych od klientów, w tym w szczególności informacji o błędach, wydłuża cykl procesu i może powodować spadek zadowolenia klientów. Aby zapewnić jakość, należy wytwarzać kod „odporny na błędy” w oparciu o testy, eliminowanie kodu niepoddającego się automatycznym testom oraz ciągłą integrację fragmentów kodu (Poppendieck, Poppendieck, 2007). W zakresie tworzenia wiedzy zalecane jest wytwarzanie oprogramowania $\mathrm{w}$ oparciu o naukowe podejście do tworzenia hipotez, przeprowadzanie eksperymentów oraz wybór alternatyw, jak również korzystanie z najlepszych dostępnych praktyk i standardów. Ostateczne decyzje, których skutków nie da się odwrócić, powinny być podejmowane w najpóźniejszym dopuszczalnym momencie. Oprogramowanie powinno być elastyczne i umożliwiać dodawanie dowolnych funkcjonalności w dowolnym momencie, a kod powinien być "odporny na zmiany”, co nie oznacza, że należy dowolnie dodawać funkcjonalności. Oprogramowanie powinno być przygotowane do elastycznej modyfikacji i dodawania funkcjonalności, jednakże modyfikacje, zmiany i nowe funkcjonalności należy dodawać tylko w przypadku spełnienia zasady $\mathrm{Pa}$ reto (funkcjonalności zaspokajające większość potrzeb). Omówione czynniki prowadzą do szybkiego dostarczania oprogramowania. Zasady lean w szczupłym wytwarzaniu oprogramowania obejmują również szacunek dla ludzi oraz optymalizację całego strumienia wartości (Poppendieck, Poppendieck, 2007). Eliminowanie strat nie może być skupione na działaniach lokalnych. Przykładowo wybór języka programowania optymalnego z punktu widzenia kompetencji programistów nie zawsze jest optymalny dla integracji z systemami klientów czy obsługi zgłoszeń serwisowych. Przykładowe straty w IT w odniesieniu do 7 typów strat znanych $\mathrm{z}$ lean $\mathrm{w}$ produkcji przedstawia tabela 2 . W tabeli zestawiono straty dotyczące oprogramowania, jak również sprzętu.

Analogicznie jak w lean manufacturing przy wdrażaniu lean w IT należy brać pod uwagę nie tylko straty (jap. muda), ale również zmienność (jap. muri) oraz przeciążenie (jap. mura). Nierównomierne obciążenie pracą należy eliminować poprzez odpowiednie systemy raportowania zakończenia zadań i rozdziału bieżących zadań, a w dłuższej perspektywie poprzez harmonogramowanie pracy poszczególnych zespołów. Menedżerowie powinni stosować techniki poziomowania (jap. heijunka) rodzajów oraz ilości zadań w odniesieniu do poszczególnych pracowników, jak i jednostek organizacyjnych (np. zespołów). Stopień wykorzystania zasad i praktyk lean przez menedżerów organizacji świadczących usługi IT jest relatywnie niewielki przy relatywnie dużym stopniu zapotrzebowania na nie (Kundu, Manohar, 2015).

Szczupłe wytwarzanie oprogramowania wraz z kanbanami jako istotną częścią traktowane są przez społeczność agile jako metody zwinnego wytwarzania oprogramowania (Agile Alliance, 2018a). Kanban został szczegółowo opisany i zaadaptowany na potrzeby wykorzystania w wytwarzaniu oprogramowania (Anderson, 2010). Tablica kanbanów służy wizualizacji i dostosowaniu prac w toku do zdolności produkcyjnych zespołu. Można wskazać trzy podstawowe zasady kanban w IT, takie jak: (1) wizualizacja przepływu w celu poprawy współpracy i komunikacji, (2) ograniczanie prac w toku i eliminowanie niekończących się zadań, (3) pomiar i optymalizacja cyklu wytworzenia oraz innych parametrów w celu przewidywania przyszłych problemów (Anderson, 2010). Kanbany mogą znacząco różnić się w zależności od środowiska, w którym są wykorzystywane. W wersji podstawowej istnieją trzy statusy zadań, tj. do wykonania, w toku, zakończone. Typy zadań umieszczanych na tablicach mogą obejmować m.in. scenariusze użycia i funkcjonalności. Zadania umieszczane są w odpowiednich kolumnach, które zazwyczaj wydzielone są $\mathrm{z}$ uwagi na realizowane procesy, np. identyfikacja wymagań, określenie scenariuszy, opracowanie scenariuszy, wytwarzanie scenariuszy czy implementacja. Kanbany wykorzystuje się zazwyczaj, gdy zadania i przepływ pracy są nieprzewidywalne zarówno w czasie, jak i co do zakresu oraz gdy istotne jest jak najszybsze podejmowanie zadań zakończonych przez poprzedników (sztafeta sportowa). Tablica kanban jest na bieżąco aktualizowana. Nie ma szczegółowych wytycznych, jak określać poziomy prac w toku w poszczególnych kolumnach - można stosować m.in. prawo Little’a. Wartości można również wyznaczać empirycznie i sterować nimi, obserwując stan tablicy (spiętrzenia prac w niektórych kolumnach lub brak prac w innych kolumnach). Należy dokonywać przeglądów zadań i nie tworzyć zbyt skomplikowanych tablic (w odniesieniu do typów zadań czy procesów), gdyż prowadzi to do powrotu do modelu kaskadowego. Tablice kanban powinny wskazywać, które zadania są najpilniejsze. Dobrą praktyką jest umieszczanie zadań pilnych u góry tablicy.

Tablice kanban i tablice zadań SCRUM (Schwaber, Beedle, 2002) mają wiele podobieństw (Kniberg, Skarin, 2010). Decyzja o wykorzystaniu jednej lub drugiej metody jest mocno zależna od specyfiki organizacji i nie da się stwierdzić, która metoda jest lepsza. Najważniejszym wyróżnikiem kanban jest odejście stałych cykli iteracji (sprintów) w SCRUM (ang. Time-boxed work-in-progress), ustanowienie limitów prac $\mathrm{w}$ toku dla poszczególnych procesów i bieżąca wizualizacja stanu prac. Z tego powodu kanban i lean bywają uważane za metodę i podejście samo w sobie nie zaś za metody w ramach podejścia zwinnego. Istnieją jednak podejścia wykorzystujące SCRUM i kanban, np. SCRUMban (Ladas, 2009). X. Wang i inni (2012) przeanalizowali 30 przypadków wykorzystania podejścia lean i podejścia agile. Prawie dwie trzecie przypadków dotyczyło wykorzystania koncepcji lean w celu usprawniania istniejących procesów zwinnego wytwarzania oprogramowania lub wsparcia wdrażania podejścia zwinnego. Po- 
Tabela 2. Przykłady strat w IT w odniesieniu do kategorii strat znanych z produkcji

\begin{tabular}{|c|c|}
\hline Straty & Przykłady w IT \\
\hline Nadprodukcja & $\begin{array}{l}\text { Wytwarzanie zbędnego kodu } \\
\text { Wytwarzanie zbędnych funkcjonalności, modułów i aplikacji }\end{array}$ \\
\hline Zbędny ruch & $\begin{array}{l}\text { Niedostateczne możliwości diagnostyki zdalnej, niewłaściwa organizacja „helpdesk”, brak } \\
\text { możliwości rozwiązania problemów przez użytkownika (obsługi autonomicznej) } \\
\text { Niewłaściwie opracowane scenariusze użycia } \\
\text { Naprawy i ponowne testy systemu } \\
\text { Brak integracji systemów np. w zakresie logowania } \\
\text { Niewłaściwa organizacja prac serwisowych w zakresie sprzętu, np. w serwerowniach }\end{array}$ \\
\hline Oczekiwanie & $\begin{array}{l}\text { Oczekiwanie podczas wytwarzania systemu } \\
\text { Oczekiwanie podczas użytkowania systemu } \\
\text { Niewystarczające zasoby (procesory, przepustowość itp.) - długie czasy reakcji aplikacji } \\
\text { Procedury wymagające akceptacji, autoryzacji } \\
\text { Brak danych } \\
\text { Utrzymanie oprogramowania i sprzętu powodujące przestoje systemu }\end{array}$ \\
\hline Zbędny transport & $\begin{array}{l}\text { Brak integracji systemów - konieczność eksportu/importu danych } \\
\text { Niewłaściwa organizacja prac serwisowych w zakresie sprzętu } \\
\text { Niepotrzebny przepływ zadań pomiędzy zespołami }\end{array}$ \\
\hline Nadmierne zapasy & $\begin{array}{l}\text { Nadmiarowy sprzęt np. w zakresie przestrzeni dyskowej lub mocy obliczeniowej } \\
\text { Nadmiarowa redundancja danych, np. składowanych lokalnie przez wielu użytkowników } \\
\text { Nadmiarowe licencje } \\
\text { Niewykorzystywane zasoby z uwagi na oczekiwanie na testy klienta } \\
\text { Spam }\end{array}$ \\
\hline Wady & $\begin{array}{l}\text { Oprogramowanie o niewłaściwych funkcjonalnościach } \\
\text { Błędny kod } \\
\text { Awarie oprogramowania i awarie sprzętu } \\
\text { Nieautoryzowane zmiany } \\
\text { Błędy ludzkie }\end{array}$ \\
\hline $\begin{array}{l}\text { Nadmierne } \\
\text { przetwarzanie }\end{array}$ & $\begin{array}{l}\text { Dalsze przetwarzanie kodu zawierającego błędy } \\
\text { Ręczne opracowywanie raportów } \\
\text { Nadmiarowe oprogramowanie (np. funkcjonalności) } \\
\text { Czynności wykonywane kilkukrotnie }\end{array}$ \\
\hline $\begin{array}{l}\text { Niewykorzystany } \\
\text { potencjał ludzki }\end{array}$ & $\begin{array}{l}\text { Brak zarządzania wiedzą } \\
\text { Źle zaadresowany program szkoleń i rozwoju kadry } \\
\text { Źle zorganizowane stanowiska pracy }\end{array}$ \\
\hline
\end{tabular}

Źródło: opracowanie własne

zostałe przypadki dotyczą stosowania: (1) podejścia zwinnego wewnątrz zespołu, a lean we współpracy $\mathrm{z}$ innymi jednostkami, (2) równoległego i niezależnego stosowania lean i agile (1 przypadek) oraz (3) odejścia od agile w stronę lean. Ostatnia kategoria dotyczy głównie odejścia od określonych czasowo sprintów stosowanych w SCRUM na rzecz kanban, ograniczania pracy w toku i ciągłej wizualizacji. Można zatem uznać, że jest to odejście od SCRUM-owych sprintów jako metody, a nie samych zasad agile, co jest zgodne $\mathrm{z}$ rozumieniem kanbanów jako jednej z metod zwinnych (Agile Alliance, 2018b). Kanban jest szczególnie skuteczny w przypadku prac serwisowych, utrzymaniowych oraz usług pomocniczych, co wynika z większej niepewności i zmian częstszych niż dopuszczalnych przy stosowaniu sprintów. Organizacje dojrzałe w zakresie stosowania agile zastępują rygory czasowe wynikające ze SCRUM podejściem lean skupionym na ciągłym przepływie. Tylko niektóre elementy lean są powszechnie stosowane w IT, tj. skupienie na eliminacji strat i kanban (Wang i in., 2012). Zasady szczupłego wytwarzania są zgodne z 12 zasadami Agile Manifesto (Beck i in., 2001), gdyż podkreślają znaczenie jakości, skupienie na ludziach, skracanie cykli i zwiększanie elastyczności. Tablice kanban są często stosowane w zarządzaniu różnego rodzaju projektami innymi niż projekty informatyczne. Dotyczy to szczególnie projektów o nie w pełni sprecyzowanych wymaganiach i z dużą zmiennością oczekiwań klientów. Stąd relatywnie większa popularność kanbanów niż innych technik lean $\mathrm{w}$ projektach IT. Tablice kanban w IT i SCRUM-owe tablice zadań (Perry, 2008) coraz częściej przybierają 
formę wirtualną (por. rys. 3), co umożliwia: (1) lepsze śledzenie pracy, (2) lepszą współpracę (w szczególności w geograficznie rozproszonych zespołach), integrację ze stosowanymi systemami (np. śledzenia i naprawy błędów w oprogramowaniu, kontroli wersji), (3) eliminowanie opóźnień w podejmowaniu decyzji pojawiających się przy tradycyjnych tablicach, (4) wygodne archiwizowanie informacji o przebiegu projektów na cele analiz. Poważnym zagrożeniem tablic wirtualnych jest mniejsze skupienie na pracy z ludźmi i interakcji między pracownikami oraz zawodność (gdyż tablice wirtualne mogą być zawodne, jak każde oprogramowanie). Szczegółowe porównanie wad i zalet tablic wirtualnych oraz tradycyjnych SCRUM przedstawił T. Perry (2008). Porównanie to jest prawdziwe również dla kanbanów. Wirtualna tablica kanban jest przykładem lean w IT (opiera się na adaptacji narzędzia lean, tj. kanban na potrzeby wytwarzania oprogramowania) i IT w lean (wsparcie IT dla kanban).

Znane są przykłady wdrożenia lean 6 sigma (Pillai i in., 2012) w procesie wytwarzania oprogramowania obejmujące zastosowanie powszechnie stosowanych narzędzi statystycznych i niestatystycznych znanych z 6 sigma (Harry, Schroeder, 2000). A. Pillai i inni (2012) przedstawili praktyczne zastosowanie programu lean 6 sigma (L6S), który umożliwił osiągnięcie korzyści strategicznych poprzez identyfikację potencjalnych innowacji oraz poprawę wy- ników finansowych. Ciekawym przykładem zastosowania L6S w organizacjach usługowych jest wdrożenie systemu IT będące celem programu L6S i służące osiągnięciu jego założeń (Fraser, Fraser, 2011).

ITIL (ang. IT Infrastructure Library) to model referencyjny, zestaw szczegółowych praktyk stosowany w zarządzaniu usługami IT, obejmujący 5 obszarów, tj. (1) strategia, (2) projektowanie, (3) przekazywanie, (4) eksploatacja, (5) ciągłe usprawnianie (Axelos, 2017). Nie jest on przeciwstawny czy wykluczający się z podejściem lean czy agile. Agile skupia się na wytwarzaniu oprogramowania, a ITIL - na zarządzaniu usługami IT. Lean bardziej skoncentrowany jest na metodycznym podejściu, a ITIL specyfikuje najlepsze praktyki. ITIL pozwala dokonać porównań i na tej podstawie wskazywać obszary potencjalnych usprawnień. Z kolei podejście lean skupia się na sposobie przeprowadzania usprawnień. Przykładem jednoczesnego stosowania ITIL i lean jest wykorzystanie lean 6 sigma w celu usprawnienia procesów ITIL przedstawione przez A. Pillai i innych (2014), a będące rozwinięciem ich wcześniejszych badań (Pillai i in., 2012). CMMI (ang. Capability Maturity Model Integration) (CMMI Insitute, 2017) to model dojrzałości organizacji wytwarzających oprogramowanie obejmujący: (1) inżynierię systemu, (2) inżynierię oprogramowania, (3) zintegrowany rozwój produktów i procesów oraz (4) współpracę z dostawcami.

Tabela 3. Lean $\mathrm{w}$ IT a lean $\mathrm{w}$ produkcji

\begin{tabular}{|c|c|c|c|}
\hline Działanie & Produkcja & IT & Korzyści w IT \\
\hline $\begin{array}{l}\text { Analiza } \\
\text { strumienia wartości }\end{array}$ & \multicolumn{2}{|l|}{$\begin{array}{l}\text { Analiza wartości } \\
\text { VoC (ang. Voice of Customer) } \\
\text { VSM (ang. Value Stream Mapping) }\end{array}$} & $\begin{array}{l}\text { Mniej kompleksowe systemy } \\
\text { Niższe koszty } \\
\text { Podział zadań }\end{array}$ \\
\hline Eliminacja strat & $\begin{array}{l}5 S \\
\text { JiT (ang. Just in time) } \\
\text { Kanban } \\
\text { Przepływ } 1 \text { sztuki } \\
\text { SMED (ang. Single Minute } \\
\text { Exchange of Die) }\end{array}$ & $\begin{array}{l}5 \mathrm{~S} \text { w biurze } \\
\text { Metodyki zwinne } \\
\text { Outsourcing } \\
\text { Sztafeta sportowa (ang. roadrunner, } \\
\text { przekazywanie zadań w momencie } \\
\text { ukończenia) }\end{array}$ & $\begin{array}{l}\text { Lepsze dopasowanie do potrzeb } \\
\text { Lepsze planowanie i dostawy } \\
\text { Większa elastyczność }\end{array}$ \\
\hline $\begin{array}{l}\text { Eliminacja } \\
\text { nierównomierności }\end{array}$ & Heijunka & $\begin{array}{l}\text { CFD (ang. Cumulative Flow Diagrams) } \\
\text { Metodyki zwinne, kanban w IT }\end{array}$ & $\begin{array}{l}\text { Większa efektywność zasobów } \\
\text { Wyższa jakość }\end{array}$ \\
\hline System ssący & Kanban & $\begin{array}{l}\text { Iteracyjne wytwarzanie } \\
\text { oprogramowania } \\
\text { Kanban w IT } \\
\text { Oprogramowanie dostosowane do } \\
\text { klienta }\end{array}$ & $\begin{array}{l}\text { Mniejsze zamrożenie środków } \\
\text { obrotowych i robót w toku } \\
\text { Zaangażowanie klienta w proces } \\
\text { Zwiększony przychód }\end{array}$ \\
\hline Skupienie na jakości & $\begin{array}{l}6 \text { sigma } \\
\text { Andon (kontrola wizualna) } \\
\text { CtQ } \\
\text { Poka-yoke (zapobieganie błędom) } \\
\text { SPC (ang. Statistical Process } \\
\text { Control) }\end{array}$ & $\begin{array}{l}\text { CtQ (ang. Critical to Quality) } \\
\text { SOA, modularność oprogramowania } \\
\text { Systemy monitorowania } \\
\text { Zautomatyzowane testy } \\
\text { Automatyczne sprawdzanie } \\
\text { poprawności danych }\end{array}$ & $\begin{array}{l}\text { Szybsze dostarczenie systemu } \\
\text { Wyższa jakość systemów }\end{array}$ \\
\hline Ciągłe doskonalenie & Kaizen & $\begin{array}{l}\text { CMMI } \\
\text { ITIL }\end{array}$ & $\begin{array}{l}\text { Oszczędności } \\
\text { Usprawnienia } \\
\text { Wzrost wiedzy }\end{array}$ \\
\hline
\end{tabular}

Źródto: opracowanie własne na podstawie: Vajna, 2015 
Istnieje model CMMI dla świadczenia usług IT (CMMI-SVC) (CMMI Product Team, 2010) uzupełniony o procesy, praktyki i cele wynikające z najlepszych praktyk lean (Kundu, Manohar, 2012). Zgodnie z tym modelem, lean i CMMI są w większości komplementarne. Tylko kilka praktyk lean dotyka tych samych zagadnień co praktyki CMMI, ale się nie wykluczają. ITIL i CMMI mają na celu ciągłe doskonalenie i w pewnym sensie stanowią w IT analogię do kaizen znanego z produkcji.

Zestawienie wykorzystania różnych narzędzi lean $\mathrm{w}$ IT $\mathrm{w}$ odniesieniu do zasad lean znanych $\mathrm{z}$ produkcji przedstawia tabela 3 . W literaturze można znaleźć również przewodnik z praktycznymi poradami, jak wdrażać zasady lean w IT (Orzen, Paider, 2016).

\section{Lean w IT - przykład zastosowania wybranych technik}

0 pisane dalej przypadki zastosowania praktyk lean pochodzą z małej polskiej firmy wytwarzającej oprogramowanie do systemów identyfikacji radiowej (RFID) (Buczacki, Gladysz, 2018). Przedsiębiorstwo zajmuje się również projektowaniem systemów identyfikacji radiowej i ich instalacja u klientów. Z uwagi na charakter prowadzonej działalności większość działań (związanych z instalacją systemów RFID) ma charakter niepowtarzalny. Jest to przedsiębiorstwo, w którym ok. $75 \%$ czasochłonności zadań stanowią prace o charakterze projektowym. Jedynie ok. 25\% działań związanych $\mathrm{z}$ wytwarzaniem oprogramowania to prace wdrożeniowe

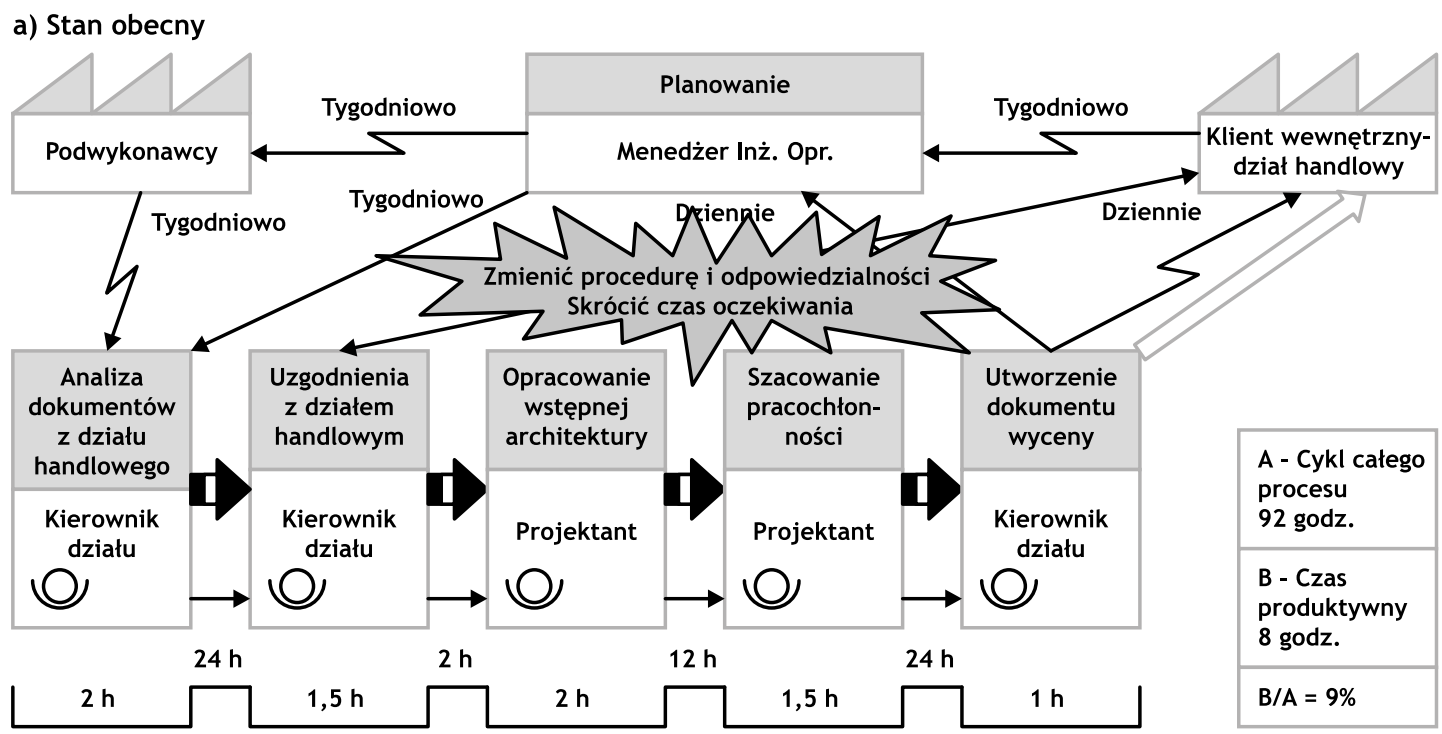

b) Stan docelowy

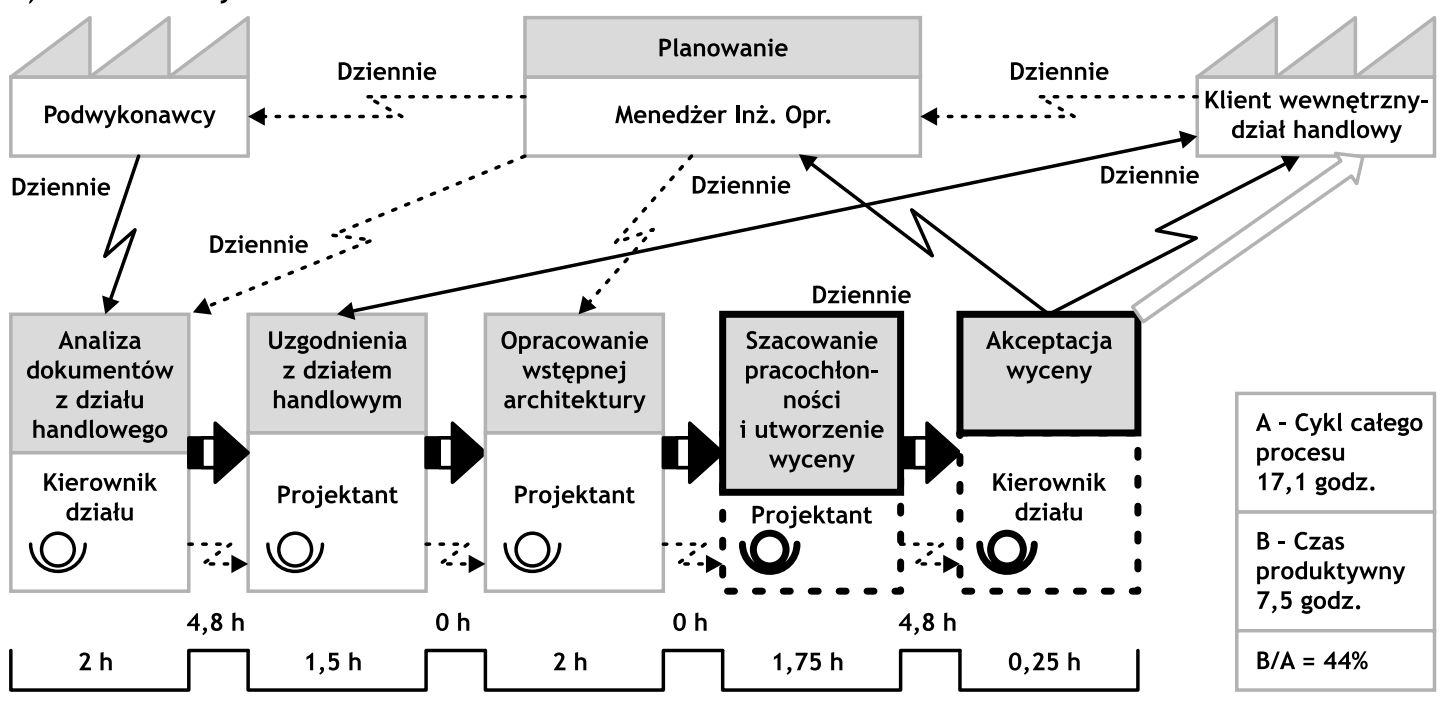

Legenda:
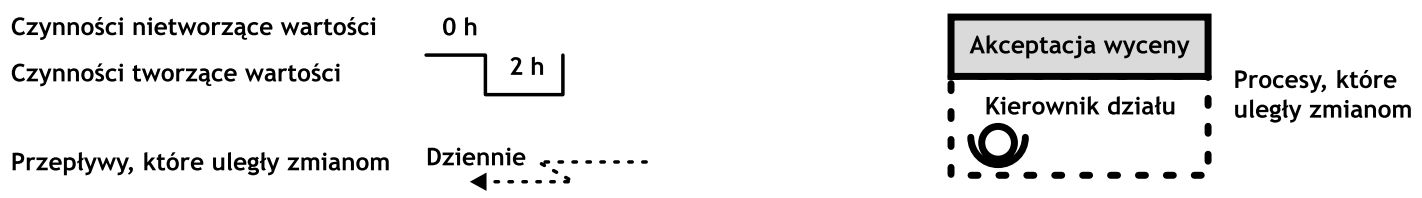

Rys. 2. Przykładowa mapa strumienia wartości w IT: a) stan obecny; b) stan docelowy

Źródto: opracowanie wtasne 


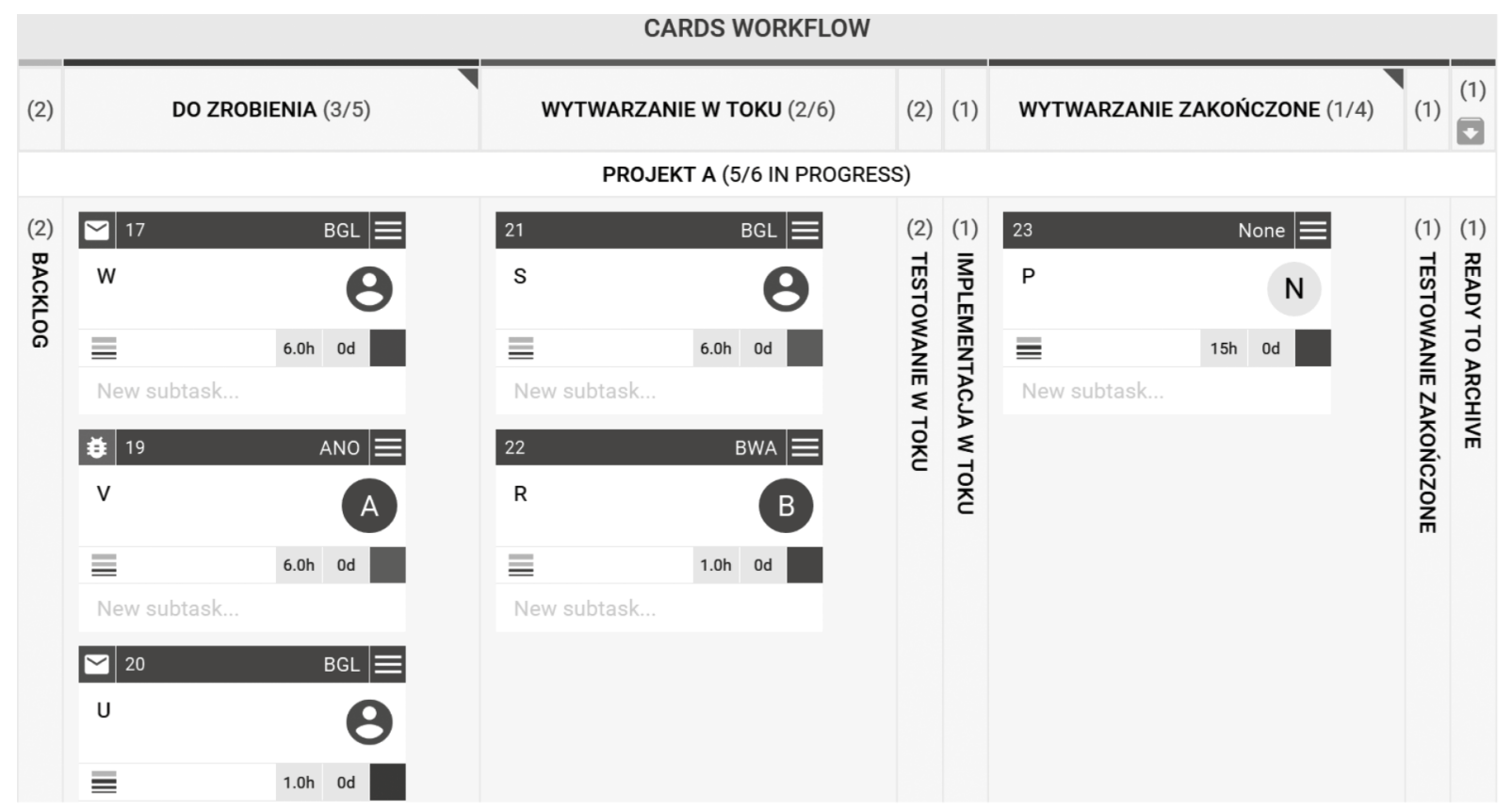

Rys. 3. Idea prostej wirtualnej tablicy kanban w IT w oprogramowaniu kanbanize.com Źródto: opracowanie wtasne

i adaptacje istniejących rozwiązań. Firma zatrudnia kilkanaście osób, z czego prawie 50\% stanowią pracownicy działu inżynierii oprogramowania, $20 \%$ działu handlowego, $20 \%$ działu instalacji, a $10 \%$ pozostali. Struktura organizacyjna firmy ma charakter macierzowy. Z jednej strony pracownicy zatrudnieni są w działach (oprogramowania, handlowym, instalacji), a $\mathrm{z}$ drugiej - zaangażowani są $\mathrm{w}$ realizację konkretnych projektów zarządzanych przez wyznaczone osoby. Jako proces wymagający usprawnienia podczas cotygodniowych spotkań kierowników działów wskazano proces przygotowania wyceny oprogramowania. $Z$ uwagi na brak powtarzalności wycena oprogramowania każdorazowo wymaga zaangażowania działu inżynierii oprogramowania w zakresie szacowania pracochłonności projektu. Pracochłonność szacowana jest przez projektanta w oparciu o dokumentację i uzgodnienia $\mathrm{z}$ działem handlowym. Kierownik działu inżynierii oprogramowania tworzył dokument wyceny na podstawie szacunków projektanta, które weryfikuje. Jest to miejsce, w którym występowała strata $\mathrm{z}$ uwagi na powtórne wykonywanie czynności przez kierownika. Zadania planowano w cyklu tygodniowym, co usztywniało działania i zmniejszało elastyczność reagowania na bieżące zmiany. Długi cykl przygotowania wyceny powodował opóźnienia w komunikacji z klientami i utratę szans sprzedażowych. Proces przygotowania wyceny poddano mapowaniu strumienia wartości i wskazano czynności tworzące wartość i nietworzące wartości (rys. 2).

Z pomiaru wynika, że $81 \%$ cyklu stanowi oczekiwanie dokumentu na dalszy etat procesu (rys. 2a). Aby skrócić cykl procesu, zmieniono procedurę i odpowiedzialności. Za kontakty z działem handlowym odpowiedzialny jest bezpośrednio projektant, co zapewnia ciągłość przepływu. Projektant wykonuje kolejne zadania bez przestoju, co miało miejsce w przypadku oczekiwania na przekazanie zadań przez kierownika działu (rys. 2b). Sterowanie pracami odbywa się codziennie, zamiast cotygodniowo. Przytoczone mapowanie procesów adresuje bezpośrednio następujące zasady lean software development
(Poppendieck, Poppendieck, 2003; 2007): eliminowanie strat, dostarczanie zadań w najwcześniejszym możliwym momencie, delegowanie uprawnień i autoryzowanie, myślenie globalne o całym systemie i rozwiązaniu. Mapa stanu docelowego została opracowana z uwzględnieniem typowych strat w IT (por. tab. 1), a rozwiązanie ma na celu wyeliminowanie strat, takich jak: bariery organizacyjne i zadania zarządcze, wielozadaniowość, oczekiwanie i zbędny ruch, oczekiwanie na możliwość rozpoczęcia zadania, wielokrotne zatwierdzanie.

Schemat prostej tablicy kanban zastosowanej w firmie przy wytwarzaniu oprogramowania przedstawia rysunek 3.

Zadania w polach „backlog” i „do zrobienia” umieszczane są przez kierownika działu wraz z określeniem niezbędnych umiejętności. Programiści podejmują zadania i umieszczają je w polu ,wytwarzanie - w toku”, po zakończeniu w polu ,wytwarzanie - zakończone". Z tego pola zadania podejmowane są analogicznie przez testerów i umieszczane w polu „testowanie - w toku”, a po zakończeniu „testowanie - zakończone”. Po zakończeniu testowania zadania przechodzą do „implementacji”, a następnie otrzymują status „do archiwizacji”. Zadania „do archiwizacji” przekazywane są przez kierownika działu kierownikowi projektu.

Przedstawiona tablica kanban pozwala na bieżąco kontrolować stan pracy w toku, unikać spiętrzeń pracy oraz zapewnia minimalizację czasów bezczynności, gdyż zadania przekazywane i podejmowane są tak szybko, jak tylko jest to możliwe. Po wprowadzeniu tablicy kanban ilość zadań niedostarczonych w terminie zmniejszyła się o $30 \%$, a czasy oczekiwania zadań w kolejce zmalały o $25 \%$.

\section{Podsumowanie}

W artykule przedstawiono typowe marnotrawstwa pojawiające się w branży IT. Omówiono je i wskazano podstawowe sposoby ich eliminacji zgodnie z koncepcją lean management. Szczególnie rozwiniętym oraz opisanym 
przez naukowców i praktyków obszarem zastosowania lean w IT jest szczupłe wytwarzanie oprogramowania. Zostało ono scharakteryzowane poprzez wskazanie strat i zasad szczupłego wytwarzania oprogramowania. Na szczególną uwagę ze względu na relatywnie częste wykorzystanie zasługuje zastosowanie tablic kanban w szczupłym wytwarzaniu oprogramowania. Społeczność agile traktuje szczupłe wytwarzanie oprogramowania jako jeden ze sposobów realizacji zasad zwinnego wytwarzania oprogramowania. Stopień wykorzystania praktyk i zasad lean w IT nie jest dobrze zbadany. Istnieją nieliczne opracowania podejmujące tę tematykę. Nie wynika to jednak $\mathrm{z}$ faktu małego zapotrzebowania na lean $\mathrm{w}$ IT, a $\mathrm{z}$ relatywnie krótkiego okresu rozpoznania zalet lean w odniesieniu do IT. Różnice w zapotrzebowaniu i stopniu wykorzystania wskazują, że praktyki lean są obszarem zainteresowania menedżerów IT. Jednocześnie wielkość tych różnic może stanowić podstawę do wyznaczania priorytetów w zakresie implementacji zasad i praktyk lean w IT. Przygotowane zestawienie zasad i praktyk lean możliwych do zastosowania w branży IT może stanowić dla praktyków wytyczne i model referencyjny pozwalający wskazać i wybrać możliwe obszary zastosowania lean i związane z tym działania. Przedstawiony przykład zastosowania VSM i tablic kanban dowodzi, że wdrożenie zasad lean w branży IT może przynosić wymierne korzyści.

\section{dr inż. Bartłomiej Gładysz \\ Politechnika Warszawska \\ Wydział Inżynierii Produkcji \\ ORCID: 0000-0003-0619-0194 \\ e-mail: bartlomiej.gladysz@pw.edu.pl}

\section{Bibliografia}

[1] Agile Alliance (2018a), Subway Map to Agile Processes, https:// www.agilealliance.org/agile101/subway-map-to-agile-practices, access date: 16.10.2018.

[2] Agile Alliance (2018b), What is Kanban?, https://www.agilealliance.org/glossary/kanban, access date: 20.10.2018.

[3] Anderson D. (2010), Kanban: Successful Evolutionary Change for Your Technology Business, Blue Hole Press, Sequim.

[4] Axelos (2017), What is ITIL Best Practice? https://www.axelos. com/best-practice-solutions/itil, access date: 14.10.2018.

[5] Beck K. i inni (2001), Manifest programowania zwinnego, http://agilemanifesto.org, data dostępu: 19.10.2018 r.

[6] Bell S., Orzen M. (2016), Lean IT: Enabling and Sustaining your Lean Transformation, Productivity Press, New York.

[7] Buczacki A., Gladysz B. (2018), Systems Engineering in SMEs - A Case of RFID Solutions Provider, „Multidisciplinary Aspects of Production Engineering", Vol. 1, No. 1, pp. 249-255.

[8] CMMI Insitute (2017), http://cmmiinstitute.com, access date: 14.10.2018.

[9] CMMI Product Team (2010), CMMI-SVC, V1.3, Carnegie Mellon, Hanscom AFB.

[10] Fraser N., Fraser J. (2011), Lean Six Sigma Applied to the Customer Services Process Within the Commercial Finance Organization - An Empirical Case Study, „International Journal of Business and Social Science", Vol. 2, No. 9, pp. 24-36.
[11] Gladysz B., Buczacki A. (2017), Wireless Technologies for Lean Manufacturing - A Literature Review, Proceedings of 24th ICPR 2017, DEStech, Poznan, pp. 7-12.

[12] Gladysz B., Santarek K., Lysiak C. (2018), Dynamic Spaghetti Diagrams. A Case Study of Pilot RTLS Implementation, [in:] A. Burduk, D. Mazurkiewicz (eds.), Intelligent Systems in Production Engineering and Maintenance - ISPEM 2017, Springer, Cham, pp. 238-248.

[13] Harry M., Schroeder R. (2000), Six Sigma: The Breakthrough Management Strategy Revolutionizing the World's Top Corporations, Currency/Doubleday, New York.

[14] Kniberg H., Skarin, M. (2010), Kanban i Scrum - jak uzyskać najlepsze $z$ obu, C4Media.

[15] Kundu G., Manohar B. (2012), A Unified Model for Implementing Lean and CMMI for Services Best Practices, „Asian Journal on Quality", Vol. 13, No. 2, pp. 138-162.

[16] Kundu G., Manohar B. (2015), How do the Practitioners Perceive Relevancy of Lean Practices in IT Support Services? „TQM Journal”, Vol. 27, No. 5, pp. 648-668.

[17] Ladas C. (2009), Scrumban - Essays on Kanban Systems for Lean Software Development, Modus Cooperandi Press, Seattle.

[18] Orzen M., Paider T. (2016), The Lean IT Field Guide: A Roadmap for Your Transformation, CRC Press, Boca Raton.

[19] Perry T. (2008), Drifting Toward Invisibility: The Transition to the Electronic Task Board, [in:]: Proceedings of the Agile 2008, IEEE, Toronto, pp. 496-500.

[20] Pillai A., Pundir A., Ganapathy L. (2012), Implementing Integrated Lean Six Sigma for Software Development: A Flexibility Framework for Managing the Continuity: Change Dichotomy, "Global Journal of Flexible Systems Management”, Vol. 13, No. 2, pp. 107-116.

[21] Pillai A., Pundir A., Ganapathy L. (2014), Improving Information Technology Infrastructure Library Service Delivery Using an Integrated Lean Six Sigma Framework, ,Journal of Software Engineering and Applications", No. 7, pp. 483-497.

[22] Poppendieck M., Poppendieck T. (2003), Lean Software Development: An Agile Toolkit, Addison-Wesley Professional, Upper Saddle River.

[23] Poppendieck M., Poppendieck T. (2007), Implementing Lean Software Development: From Concept to Cash, AddisonWesley, Stoughton.

[24] Rivera T. (2010), How and Why to Create Value Stream Maps for Software Engineering Projects, https://tinyurl.com/yc4sn7po, access date: 14.10.2017.

[25] Rodriguez P., Partanen J., Kuvaja P., Oivo M. (2014), Combining Lean Thinking and Agile Methods for Software Development, Proceedings of $47^{\text {th }}$ HICCS, IEEE, Waikaloa, pp. 4770 -4779 .

[26] Schwaber K., Beedle M. (2002), Agile Software Development with Scrum, Prentice Hall, Upper Saddle River.

[27] Vajna Z. (2015), Lean Tool in IT Sector, „Expert Journal of Business and Management", Vol. 3, No. 2, pp. 82-89.

[28] Wang X., Conwoy K., Cawley O. (2012), „Leagile” Software Development: An Experience Report Analysis of the Application of Lean Approaches in Agile Software Development, ,Journal of Systems and Software", Vol. 85, No. 6, pp. 1287-1299.

[29] Womack J.P., Jones D.T. (1996), Lean Thinking. Banish Waste and Create Wealth in Your Corporation, Free Press, New York. 
[30] Wójcik P. (2013), Znaczenie stadium przypadku jako metody badawczej w naukach o zarzadzaniu, „e-mentor”, Vol. 48, Nr 1, s. 17-22.

[31] Zhang P., Aikman S., Sun H. (2008), Two Types of Attitudes in ICT Acceptance and Use, „International Journal of Human-Computer Interaction", Vol. 24, No. 7, pp. 628-648.

[32] Zuppo C. (2012), Defining ICT in a Boundaryless World: The Development of a Working Hierarchy, „International Journal of Management and Information Technology", Vol. 4, No. 3, pp. 13-22.

\section{Applications of Selected Lean Management Techniques in IT Projects}

\section{Summary}

The main objective of the article is to identify lean management practices applicable for IT projects. Current state of knowledge and relations between lean management and IT projects described in the literature have been identified in it. The Author has included a list of IT-oriented wastes. Specific techniques as value stream mapping and kanban have been found to be most commonly used from the set of popular lean practices. Specific characteristics of kanbans in IT have been discussed in detail. Typical actions for any lean implementation i.e. value stream analysis, waste elimination, pull system, orientation on quality, continuous improvement have been compared for IT projects and manufacturing effecting with the table that may serve as a reference model for lean in IT practitioners. Finally, a case of small company has been discussed, showing examples of value stream mapping and kanbans applied in software engineering department, demonstrating that lean practices applied in IT may deliver tangible results.

\section{Keywords}

lean management, kanban, agile, IT

* Sponsorowany tekst popularnonaukowy 